\title{
INSTITUTO VENEZOLANO DE INVESTIGACIONES CIENTIFICAS NATURAL RADIOCARBON MEASUREMENTS VI
}

\author{
M. A. TAMERS \\ Instituto Venezolano de Investigaciones Científicas, \\ Department of Chemistry, Caracas, Venezuela
}

The I.V.I.C. laboratory continues operation using liquid scintillation spectrometry with synthesized benzene. A plastic-glass counting vessel contains $3 \mathrm{ml}$ benzene, $1 \mathrm{ml}$ commercial toluene, and concentrations of $0.4 \%$ PPO and $0.01 \%$ POPOP as scintillators. Background is $6.9 \mathrm{cpm}$ and activity of the modern standard, $95 \%$ of the activity of the NBS oxalic acid, is $21.4 \mathrm{cpm}$. In the age calculations, 5568 years is taken for the half-life of $\mathrm{C}^{14}$ and quoted errors are one standard deviation arising from the random nature of the radioactive disintegration process. Uncertainties in the half-life are not included nor are variations in the deposition rate of stratospheric radiocarbon and dilution by industrial use of fossil fuels. A.D. 1950 is employed as the reference year in the B.P. (before present) notation of ages.

\section{ACKNOWLEDGMENTS}

Close collaboration is maintained with the I.V.I.C. Dept. of Anthropol., J. M. Cruxent, head. V. García and F. Machado carry out the benzene syntheses and routine chemical analyses. A. Russo maintains the liquid scintillation counter.

\section{SAMPLE DESCRIPTIONS}

\section{GROUND WATER SAMPLES}

Considerable portions of Venezuela, including several of its principal cities, lie in semi-arid regions. Traditionally, fresh water in these areas has depended on subterranean aquifers. However, recent introduction of large bore deep wells and electric pumps, necessary for increasing living standards, developing industry, and irrigation, have resulted in lowering ground water levels. A study of the recharge characteristics of the water tables is a sine qua non for future planning in these areas.

The principal ground water aquifers of Venezuela have been investigated by radiocarbon dating of dissolved carbonate species. The results have been presented in previous date lists. Two aquifers are sampled annually in a program to observe changes caused by contamination of the atmosphere by nuclear weapons. The wells on the $\mathrm{N}$ and $\mathrm{S}$ sides of the Lake of Valencia and the Bosque Macuto municipal wells of Barquisimeto are producing modern water. The technique of sequential sampling, initiated in these cases in 1966, allows a fitting of the limestone-corrected radiocarbon dates with the fallout curve (Tamers and Scharpenseel, 1970). The method works well for Barquisimeto, but the Lake of Valencia modern waters are apparently being over-exploited and are no longer reaching the lake. This is accelerating the natural desiccation of the large continental body of water. 
Wells of Valencia Lake Basin

\begin{tabular}{|c|c|c|}
\hline & $\begin{array}{c}\text { Collection } \\
\text { (day/month/yr) }\end{array}$ & $\begin{array}{c}\mathrm{C}^{14} \\
(\% \text { of modern })\end{array}$ \\
\hline $\begin{array}{l}\text { IVIC-685. Mariara } 1 \\
\left(10^{\circ} 15^{\prime} \mathrm{N} \text { Lat, } 67^{\circ} 43^{\prime} \mathrm{W} \text { Long }\right)\end{array}$ & $14 / 1 / 70$ & $88.8 \pm 0.7$ \\
\hline $\begin{array}{l}\text { IVIC-686. Mariara } 2 \\
\left(10^{\circ} 13^{\prime} \mathrm{N} \text { Lat, } 67^{\circ} 43^{\prime} \mathrm{W} \text { Long }\right)\end{array}$ & $14 / 1 / 70$ & $99.7 \pm 0.8$ \\
\hline $\begin{array}{l}\text { IVIC-687. El Trompillo } \\
\left(10^{\circ} 4^{\prime} \mathrm{N} \text { Lat, } 67^{\circ} 48^{\prime} \mathrm{W} \text { Long }\right)\end{array}$ & $14 / 1 / 70$ & $98.8 \pm 0.8$ \\
\hline $\begin{array}{l}\text { IVIC-688. Güigüe } 1 \\
\left(10^{\circ} 5^{\prime} \mathrm{N} \text { Lat, } 67^{\circ} 47^{\prime} \mathrm{W} \text { Long }\right)\end{array}$ & $14 / 1 / 70$ & $91.5 \pm 1.0$ \\
\hline $\begin{array}{l}\text { IVIC-689. } \\
\left(10^{\circ} 5^{\prime} \mathrm{N} \text { Läigüe } 3\right. \\
\left.67^{\circ} 47^{\prime} \mathrm{W} \text { Long }\right)\end{array}$ & $14 / 1 / 70$ & $91.8 \pm 0.8$ \\
\hline \multicolumn{3}{|l|}{ Barquisimeto Wells } \\
\hline $\begin{array}{l}\text { IVIC-768. } \text { Macuto } 1 \\
\left(10^{\circ} 3^{\prime} \mathrm{N} \text { Lat, } 69^{\circ} 19^{\prime} \mathrm{W} \text { Long }\right)\end{array}$ & $12 / 5 / 70$ & $91.3 \pm 0.8$ \\
\hline $\begin{array}{l}\text { IVIC-769. } \text { Macuto } 2 \\
\left(10^{\circ} 3^{\prime} \mathrm{N} \text { Lat, } 69^{\circ} 19^{\prime} \mathrm{W} \text { Long }\right)\end{array}$ & $12 / 5 / 70$ & $92.8 \pm 0.7$ \\
\hline $\begin{array}{l}\text { IVIC-770. } \text { Macuto } 3 \\
\left(10^{\circ} 3^{\prime} \mathrm{N} \text { Lat, } 69^{\circ} 19^{\prime} \mathrm{W} \text { Long }\right)\end{array}$ & $12 / 5 / 70$ & $86.5 \pm 0.7$ \\
\hline $\begin{array}{l}\text { IVIC-771. } \text { Macuto } 5 \\
\left(10^{\circ} 3^{\prime} \mathrm{N} \text { Lat, } 69^{\circ} 19^{\prime} \mathrm{W} \text { Long }\right)\end{array}$ & $12 / 5 / 70$ & $87.1 \pm 0.8$ \\
\hline $\begin{array}{l}\text { IVIC-772. } \text { Macuto } 6 \\
\left(10^{\circ} 3^{\prime} \mathrm{N} \text { Lat, } 69^{\circ} 19^{\prime} \mathrm{W} \text { Long }\right)\end{array}$ & $12 / 5 / 70$ & $85.5 \pm 0.7$ \\
\hline $\begin{array}{l}\text { IVIC-773. Macuto } 7 \\
\left(10^{\circ} 3^{\prime} \mathrm{N} \text { Lat, } 69^{\circ} 19^{\prime} \mathrm{W} \text { Long }\right)\end{array}$ & $12 / 5 / 70$ & $91.4 \pm 0.7$ \\
\hline IVIC-774. Macuto 8 & $12 / 5 / 70$ & $85.1 \pm 0.7$ \\
\hline
\end{tabular}

II. ARCHAEOLOGIC SAMPLES

A. Venezuela

IVIC-723. Misteque

$850 \pm 60$

Charcoal obtained from mortar of piled stones, ca. $6 \mathrm{~km}$ SE Chachopo, state of Mérida, Venezuela ( $8^{\circ} 56.0^{\prime} \mathrm{N}$ Lat, $70^{\circ} 46.7^{\prime} \mathrm{W}$ Long). Assoc. with simple pottery, trade pottery, stones, manos, animal bones, ashes. This is lst date for region of Chachopo. Other dates for Venezuelan Andes discussed previously (Wagner, 1967). Coll. 1970 and subm. by E. Wagner, I.V.I.C., who estimated age to be 500 to 1000 B.P. Comment (E.W.): date confirms age estimation from artifacts.

IVIC-724. Ensillada de Mucuyupú

$200 \pm 60$

Small charcoal sample from cave NW of Timotes, on boundary between states of Mérida and Trujillo, Venezuela $\left(9^{\circ} 1.1^{\prime} \mathrm{N}\right.$ Lat, $70^{\circ} 44.9^{\prime}$ W Long). Assoc. with simple pottery and pieces of shell necklace. Coll. 
1970 and subm. by E. Wagner. This is 1st date from cave in elevated zone in Venezuelan Andes. Estimated age, 400 to 1000 B.P. Comment (E.W.): probably intrusive charcoal.

\section{Taima-taima series}

This paleo-indian kill site $\mathrm{W}$ of Vela de Coro, state of Falcón, Venezuela ( $11^{\circ} 30^{\prime} \mathrm{N}$ Lat, $69^{\circ} 30^{\prime} \mathrm{W}$ Long) has been under intensive investigation by the I.V.I.C. Anthropol. Dept. for past $10 \mathrm{yr}$ (Cruxent, 1967). Pleistocene animal bones have been dated at 13,010 \pm 280 and $14,440 \pm 435$ B.P. (IVIC-191-1 and IVIC-191-2, R., 1966, v. 8, p. 206) for non-carbonate fractions and $7590 \pm 100$ B.P. (IVIC-191-B, R., 1969, v. 11, p. 407) for carbonates. The fluorine content was $1.0 \%$ (Tamers, 1969b). A wood sample, presumably preserved by high sulfur content of soil, provided date of $11,860 \pm 130$ B.P. (IVIC-655, R., 1970, v. 12, p. 516). Evidence for man is based on numerous cutting scars on bones and stone points (Cruxent, pers. commun.).

IVIC-657. Taima-taima $A, 0.65$ to $0.75 \mathrm{~m}$

$$
\begin{aligned}
& 9650 \pm 80 \\
& 7700 \text { B.c. }
\end{aligned}
$$

Black clay, Profile A, Sec. 38, NE corner. 1.5\% non-rootlet, noncarbonate carbon content.

\section{IVIC-658. Taima-taima $A, 0.75$ to $0.85 \mathrm{~m}$}

$9650 \pm 110$

Black clay, Profile A, Sec. 38, NE corner. $2.9 \%$ non-rootlet, noncarbonate carbon content.

IVIC-659. Taima-taima $A, 0.85$ to $0.95 \mathrm{~m}$

$$
10,140 \pm 90
$$
8190 в.C.

Black clay, Profile A, Sec. 38, NE corner. 3.9\% non-rootlet, noncarbonate carbon content.

IVIC-660. Taima-taima A, 1.50 to $1.65 \mathrm{~m}$

$$
12,660 \pm 120
$$$$
10,710 \text { в.C. }
$$

Gray sand, Profile A, Sec. 38, NE corner. $0.25 \%$ non-rootlet, noncarbonate carbon content.

IVIC-661. Taima-taima A, 1.65 to $1.80 \mathrm{~m}$

$$
12,620 \pm 120
$$

Gray sand, Profile A, Sec. 38, NE corner. $0.35 \%$ non-rootlet, noncarbonate carbon content.

\section{IVIC-662. Taima-taima $A, 1.80$ to $1.95 \mathrm{~m}$}

$$
13,390 \pm 130
$$

Gray sand, Profile A, Sec. 38, NE corner. $0.54 \%$ non-rootlet, noncarbonate carbon content.

IVIC-663. Taima-taima A, 1.95 to $2.10 \mathrm{~m}$

$13,130 \pm 130$

Gray sand, Profile A, Sec. 38, NE corner. $0.67 \%$ non-rootlet, noncarbonate carbon content. 
IVIC-664. Taima-taima A, 2.10 to $2.25 \mathrm{~m}$

$12,730 \pm 120$

Gray sand, Profile A, Sec. 38, NE corner. $0.78 \%$ non-rootlet, noncarbonate carbon content. Soil samples coll. 1969 and subm. by J. M. Cruxent and M. A. Tamers. Black clay layer is overlain by ca. $65 \mathrm{~cm}$ impermeable yellow clay. From ca. 95 to $150 \mathrm{~cm}$ is another deposit of almost carbon-free clay. The kill site bones are located in the gray sand layer, which is in the phreatic zone. Surface vegetation is sparse and xerophytic. At ca. $225 \mathrm{~cm}$ begins rock strata of tertiary period. Comment: see General Comment after Taima-taima B series.

IVIC-665. Taima-taima $B, 0.65$ to $0.75 \mathrm{~m}$

$9860 \pm 110$

Black clay, Profile B, Sec. 38 , SE corner. $1.6 \%$ non-rootlet, noncarbonate carbon content.

IVIC-666. Taima-taima $B, 0.75$ to $0.85 \mathrm{~m}$

$10,030 \pm 90$

Black clay, Profile B, Sec. 38, SE corner. $3.6 \%$ non-rootlet, noncarbonate carbon content.

IVIC-667. Taima-taima $B, 0.85$ to $0.95 \mathrm{~m}$

$10,290 \pm 90$

Black clay, Profile B, Sec. 38, SE corner. $4.8 \%$ non-rootlet, noncarbonate carbon content.

IVIC-668. Taima-taima $B, 1.50$ to $1.65 \mathrm{~m}$

$13,390 \pm 130$

Gray sand, Profile B, Sec. 38, SE corner. $0.30 \%$ non-rootlet, noncarbonate carbon content.

IVIC-669. Taima-taima $B, 1.65$ to $1.80 \mathrm{~m}$

$12,770 \pm 120$

Gray sand, Profile B, Sec. 38, SE corner. $0.37 \%$ non-rootlet, noncarbonate carbon content.

IVIC-670. Taima-taima $B, 1.80$ to $1.95 \mathrm{~m}$

$12,990 \pm 260$

Gray sand, Profile B, Sec. 38, SE corner. $0.59 \%$ non-rootlet, noncarbonate carbon content.

IVIC-671. Taima-taima B, 1.95 to $2.10 \mathrm{~m}$

$13,180 \pm 130$

11,230 в.c.

Gray sand, Profile B, Sec. 38, SE corner. $0.62 \%$ non-rootlet, noncarbonate carbon content.

IVIC-672. Taima-taima B, 2.10 to $2.25 \mathrm{~m}$

$14,010 \pm 140$

Gray sand, Profile B, Sec. 38, SE corner. $1.2 \%$ non-rootlet, noncarbonate carbon content. Soil samples coll. same time as those of Profile $\mathrm{A}$ and soil strata are similar. Previous soil sample date on Taimataima gray sand was $12,580 \pm 150$ B.P. (IVIC-627, R., 1970, v. 12, p. 516), from an adjacent area of site; agrees with these dates. 
General Comment (M.A.T.): black clay layer overlies and underlies impermeable strata and can be used to give minimum possible age of $10,290 \pm 90$ в.P. to artifacts located in gray sand. Radiocarbon dates in the gray sand are practically indistinguishable, except for IVIC-672, which is a little older. There is definite increase of carbon content with depth, contrary to other cases of soil profiles studied in Venezuela (see Sec. III). Possibly, carbon originates from a deposit at ca. $2.10 \mathrm{~m}$ depth and was partially transported upward by seasonal fluctuations of ground water level. Therefore, $14,010 \pm 140$ B.P. could be taken as oldest date for the bones. The impermeability of upper strata minimizes the possibility of a large amount of more recent carbon infiltration causing falsely young ages, as observed in work of Bonn lab. (Scharpenseel and Pietig, 1969). The age of Taima-taima kill site must lie between 11,000 and 15,000 в.P. This is oldest dated archaeologic site in South America.

\section{$\mathbf{3 6 , 6 9 0}+2310$ \\ IVIC-704. Taima-taima organic material}

Carbonaceous material, probably lignite, from $2.00 \mathrm{~m}$ depth in part of Taima-taima site with few bones. Coll. 1970 and subm. by J. M. Cruxent. Material not typical of site nor of area and must have been introduced artificially from a considerable distance. Previous clate on similar sample from Taima-taima was $>41,000$ B.P. (Y-1199, R., 1969, v. 11, p. 634), which is within $2 \sigma$ of IVIC date. Comment (J.M.C.): material cannot be considered to date Taima-taima artifacts.

\section{Caleta Abtao series}

\section{B. Chile}

Samples of loco (Concholepas concholepas) shells from 3rd marine terrace mound on Mejillones Peninsula, prov. of Antofagasta, Chile (23 $20^{\prime} \mathrm{S}$ Lat, $70^{\circ} 31^{\prime} \mathrm{W}$ Long). Coll. 1969 and subm. by G. Boisset and A. Llagostera, Univ. del Norte, Antofagasta, Chile.

\section{IVIC-679. Caleta Abtao 1}

$5030 \pm 70$ 3080 в.c.

From Site 2, Pit 2, $2.20 \mathrm{~m}$ below surface. First occupation level. Assoc. with shell fish hooks, bone and lithic instruments, plant origin cord, guano.

\section{IVIC-680. Caleta Abtao 4}

$4820 \pm 70$ 2870 в.C.

From Site 2, Pit 1, $2.40 \mathrm{~m}$ below surface. First occupation level. Assoc. with 2 shell fish hooks and 1 cactus spine fish hook.

IVIC-681. Caleta Abtao 7

$5100 \pm 130$

3150 B.C.

From Site 1, Sq. 01, $0.10 \mathrm{~m}$ below surface. Seventh (last) occupation level. Assoc. with stone points and fragments and tubular bone beads. 


\section{IVIC-682. Caleta Abtao 8}

(1) 8 melow surface. First occupation level. Assoc. with shell, bone, and cactus spine fish hooks; lithic, bone, and wood instruments; and cord.

\section{IVIC-683. Caleta Abtao 11}

From Site 1, Sq. 01, $0.40 \mathrm{~m}$ below surface. Fifth occupation level. Assoc. with shell, bone, and cactus spine fish hooks; lithic, bone, and wood instruments; and cord. Comment (M.A.T.): the 5 dates are statistically indistinguishable.

General Comment (G.B.): dates agree perfectly with archaeologic evidence. Previous date for shell fish hook culture of Quiani, Arica site was $6170 \pm 220$ B.P. (I-1348, R., 1969, v. 11, p. 102). Date for cactus spine fish hooks from same site was $5630 \pm 145$ B.P. (I-1349, R., 1969, v. 11, p. 102). In Caleta Abtao both cultures appear in all occupation levels. Since IVIC dates are close to but less than I-1349, we could say that immigrants from $\mathrm{N}$ came to Caleta Abtao at period of beginning of use of cactus spine fish hooks. Shell fish hook use persisted in Caleta Abtao longer than in N, e.g., in Quiani.

\section{Alero Rocoso de San Pedro Viejo series}

Charcoal samples from Hortado R. valley, N side, Ovalle Dept., Coquimbo prov., Chile $\left(30^{\circ} 23^{\prime} \mathrm{S}\right.$ Lat, $70^{\circ}$ 53' W Long). Coll. 1968 and 1970 and subm. by G. Ampuero B. and M. A. Rivera, Univ. de Concepción, Concepción, Chile.

\section{IVIC-727. Pichasca 1}

From Sq. D-2, Level II, $1 \mathrm{~m}$ below surface. Located in simple burial pocket without furnishings. Level occupied by hunters with knowledge of agriculture and possibly in contact with the El Molle ceramic culture. Sample date contact between Levels I and II.

\section{IVIC-728. Pichasca 2}

From Sq. D-3, Level III. Assoc. with projectile points, bone and wood tools, and food debris. Existence of basketry. Level occupied by hunters with probable beginnings of agriculture, preceramic, and before El Molle culture. Sample dated twice on separate batches of charcoal with results: $9920 \pm 110$ and $9860 \pm 110$ B.P.

\section{IVIC-729. Pichasca 3}

$4700 \pm 80$

2750 в.c.

From NW wall Sq. A-1, base of Level II. Assoc. with projectile points, basketry, and objects of wood and bone. Sample corresponds to contact between Levels II and III. Occupation by hunters with probable beginnings of agriculture. Ceramics absent. 
Goneral Comment (M.A.R.): 1st impression is that dates agree with other evidence of the 2 excavations.

\section{SOIL SAMPLES}

Radiocarbon dating of soil associations in various regions of Venezuela is one major project of the lab. Pretreatment is similar to that developed in Bonn (Scharpenseel, Tamers, and Pietig, 1968). Sample first passed through gross screen to remove large roots and stones. A slurry is then produced with distilled water and a high torque stirrer. A fine screen removes small rootlets from this suspension. Hydrochloric acid is added to eliminate carbonates and slurries centrifuged to permit decantation of supernatent liquids. After drying at $110^{\circ} \mathrm{C}$, soils are burned in usual combustion tubes and $\mathrm{CO}_{2}$ collected in ammonia bubblers. Precipitation with strontium chloride permits gravimetric analysis of non-carbonate, non-rootlet carbon content and provides material for benzene synthesis.

\section{Maracay series}

Soil association on NE bank of Lake of Valencia, in orchard of Fac. de Agron., Univ. Central in Maracay, state of Aragua, Venezuela $\left(10^{\circ} 17^{\prime} \mathrm{N}\right.$ Lat, $67^{\circ} 36^{\prime} \mathrm{W}$ Long). Surface layer of alluvial loam ca. 60 $\mathrm{cm}$ separated by ca. $135 \mathrm{~cm}$ almost carbon-free sand from fossil horizon. Coll. 1970 and subm. by R. Herrera and M. A. Tamers.

IVIC-690. Maracay A-1

$123.4 \pm 0.9 \%$ modern

Gray-black clayey soil, 0 to $0.15 \mathrm{~m}$ below surface. $1.6 \%$ non-carbonate, non-rootlet carbon content.

IVIC-691. Maracay A-2

103.4 $\pm 0.8 \%$ modern

Gray-black clayey soil, 0.15 to $0.30 \mathrm{~m}$ below surface. $1.2 \%$ noncarbonate, non-rootlet carbon content.

\section{IVIC-692. Maracay A-3}

$104.6 \pm 0.8 \%$ modern

Gray-black clayey soil, 0.30 to $0.45 \mathrm{~m}$ below surface. $0.52 \%$ noncarbonate, non-rootlet carbon content.

IVIC-693. Maracay A-4

$103.3 \pm 0.9 \%$ modern

Gray-black clayey soil, limit of this horizon, 0.45 to $0.60 \mathrm{~m}$ below surface. Mixed with yellow sand. $0.42 \%$ non-carbonate, non-rootlet carbon content.

\section{IVIC-700. Maracay A-11}

$1260 \pm 70$

Gray-black friable soil, beginning of fossil horizon. $0.50 \%$ noncarbonate, non-rootlet carbon content. 1.35 to $1.50 \mathrm{~m}$ below surface.

IVIC-701. Maracay A-12

$1650 \pm 80$

Gray-black soil, 1.50 to $1.65 \mathrm{~m}$ below surface. Second half of fossil horizon. $0.24 \%$ non-carbonate, non-rootlet carbon content. 
General Comment: it was not expected that all upper horizon saniples would be modern. Inorganic fertilizer was employed here and soil has not been recently ploughed, and certainly to no more than $30 \mathrm{~cm}$. Modern dates of IVIC-692 and IVIC-693 must be due to infiltration of recent material from upper layers, a phenomenon described elsewhere (Benzler and Geyh, 1966; Scharpenseel and Pietig, 1969). Since sand separating these layers from fossil horizon is permeable, it must be concluded that IVIC-700 and IVIC-701 are also falsely young. Values indicate only minimum ages. It is not clear to us why surface carbon infiltration is so pronounced in this particular soil.

\section{Tierra Pipe series}

Clay soil samples, brown earth of A-C horizon type in Altos de Pipe, state of Miranda, Venezuela $\left(10^{\circ} 23^{\prime} \mathrm{N}\right.$ Lat, $66^{\circ} 58^{\prime} \mathrm{W}$ Long), on steep side of Pipe hill. Previous profile gave dates of $2230 \pm 60,4220$ \pm 90 , and $5720 \pm 80$ B.P. for $15 \mathrm{~cm}$ fractions from 0.15 to $0.60 \mathrm{~m}$ (IVIC652, IVIC-653, IVIC-654, R., 1970, v. 12, p. 524). Profiles reported here continue study, Pipe 3 being ca. $50 \mathrm{~m}$ below previous samples, Pipe 4 ca. $100 \mathrm{~m}$ below, Pipe 2 ca. $50 \mathrm{~m}$ above, and Pipe 5 on hill top, slightly on opposite side with gentle slope. Coll. 1970 and subm. by R. Herrera and M. A. Tamers.

IVIC-756. Pipe 5, 0.25 to $0.35 \mathrm{~m}$

$2.3 \%$ non-rootlet, non-carbonate carbon content.

IVIC-757. Pipe 5, 0.35 to $0.45 \mathrm{~m}$

$2.1 \%$ non-rootlet, non-carbonate carbon content.

IVIC-758. Pipe 5, 0.45 to $0.55 \mathrm{~m}$

$0.91 \%$ non-rootlet, non-carbonate carbon content.

IVIC-759. Pipe 5, 0.55 to $0.65 \mathrm{~m}$

$0.56 \%$ non-rootlet, non-carbonate carbon content.

IVIC-760. Pipe 5, 0.65 to $0.75 \mathrm{~m}$

$0.53 \%$ non-rootlet, non-carbonate carbon content.

IVIC-761. Pipe 5, 0.75 to $0.85 \mathrm{~m}$

$0.26 \%$ non-rootlet, non-carbonate carbon content.

IVIC-730. Pipe 2, 0.15 to $0.30 \mathrm{~m}$

$0.42 \%$ non-rootlet, non-carbonate carbon content.

IVIC-731. Pipe 2, 0.30 to $0.45 \mathrm{~m}$

$0.34 \%$ non-rootlet, non-carbonate carbon content.
$890 \pm 60$

A.D. 1060

$$
1400 \pm 70
$$

A.D. 550

$2150 \pm 70$

200 B.C.

$2050 \pm 70$

100 B.C.

$2460 \pm 70$

510 B.C.

$2480 \pm 80$

530 B.C.

$2830 \pm 80$

880 B.C.

$5620 \pm 100$

3670 в.C. 
IVIC-732. Pipe 2, 0.45 to $0.60 \mathrm{~m}$

$0.36 \%$ non-rootlet, non-carbonate carbon content.

IVIC-733. Pipe 2, 0.60 to $0.75 \mathrm{~m}$

$0.34 \%$ non-rootlet, non-carbonate carbon content.

IVIC-734. Pipe 2, 0.75 to $0.90 \mathrm{~m}$

$0.27 \%$ non-rootlet, non-carbonate carbon content.

IVIC-735. Pipe 3, 0.15 to $0.30 \mathrm{~m}$

$2.9 \%$ non-rootlet, non-carbonate carbon content.

IVIC-736. Pipe 3, 0.30 to $0.45 \mathrm{~m}$

$2.0 \%$ non-rootlet, non-carbonate carbon content.

IVIC-737. Pipe 3, 0.45 to $0.60 \mathrm{~m}$

$1.4 \%$ non-rootlet, non-carbonate carbon content.

IVIC-738. Pipe 3, 0.60 to $0.75 \mathrm{~m}$

$1.1 \%$ non-rootlet, non-carbonate carbon content.

IVIC-739. Pipe 3, 0.75 to $0.90 \mathrm{~m}$

$0.98 \%$ non-rootlet, non-carbonate carbon content.

IVIC-740. Pipe 4, 0.15 to $0.30 \mathrm{~m}$

$1.7 \%$ non-rootlet, non-carbonate carbon content.

IVIC-741. Pipe 4, 0.30 to $0.45 \mathrm{~m}$

$1.8 \%$ non-rootlet, non-carbonate carbon content.

IVIC-742. Pipe 4, 0.45 to $0.60 \mathrm{~m}$

$1.4 \%$ non-rootlet, non-carbonate carbon content.

IVIC-743. Pipe 4, 0.60 to $0.75 \mathrm{~m}$

$0.96 \%$ non-rootlet, non-carbonate carbon content.

IVIC-744. Pipe 4, 0.75 to $0.90 \mathrm{~m}$

$0.47 \%$ non-rootlet, non-carbonate carbon content.

IVIC-745. Pipe 4, 0.90 to $1.05 \mathrm{~m}$

$0.31 \%$ non-rootlet, non-carbonate carbon content.
$6000 \pm 100$

4050 в.c.

$6820 \pm 90$

4870 в.C.

$6840 \pm 100$

4890 B.C.

A.D. 1560

$390 \pm 60$

$1030 \pm 60$

A.D. 920

$1670 \pm 70$

A.D. 280

$2330 \pm 70$

420 B.C.

$2610 \pm 80$

660 B.C.

A.D. 980

$570 \pm 60$

$1050 \pm 60$

A.D. 900

$1250 \pm 70$

A.D. 700

$1710 \pm 70$

A.D. 240

$$
2180 \pm 70
$$

230 B.C.

$2220 \pm 70$

270 B.C.

General Comment: samples all show correct date sequences with respect to stratigraphy. Ages and carbon contents increase with distance down 
slope. Previous profile dates in agreement with these tendencies. This study is being continued with more samples and various chemical analyses on the soils.

\section{Club de Campo series}

Soil samples on opposite side of Pipe Hill, in direction of settlement Club de Campo ( $10^{\circ} 23^{\prime} \mathrm{N}$ Lat, $66^{\circ} 58^{\prime} \mathrm{W}$ Long). Pipe 5 dates could be given with this series. Club de Campo 1 is ca. $50 \mathrm{~m}$ from hill top and Club de Campo 2 is ca. $100 \mathrm{~m}$ down hill. Coll. 1970 and subm. by R. Herrera and M. A. Tamers.

IVIC-748. Club de Campo $1, \quad \quad 100.4 \pm 0.8 \%$ modern 0.15 to $0.30 \mathrm{~m}$

$1.3 \%$ non-rootlet, non-carbonate carbon content.

IVIC-749. Club de Campo 1, 0.30 to $0.45 \mathrm{~m}$

A.D. 1610

$0.82 \%$ non-rootlet, non-carbonate carbon content.

IVIC-750. Club de Campo 1, 0.45 to $0.60 \mathrm{~m}$

$0.17 \%$ non-rootlet, non-carbonate carbon content.

$490 \pm 60$

IVIC-752. Club de Campo 2, 0.25 to $0.35 \mathrm{~m}$ $1.1 \%$ non-rootlet, non-carbonate carbon content.

$1330 \pm 70$ A.D. 620

IVIC-753. Club de Campo 2, 0.35 to $0.45 \mathrm{~m}$ $0.65 \%$ non-rootlet, non-carbonate carbon content.

IVIC-754. Club de Campo 2, 0.45 to $0.55 \mathrm{~m}$

$0.37 \%$ non-rootlet, non-carbonate carbon content.

General Comment: dates increase and carbon contents decrease regularly with depth. Relatively recent dates were unexpected. Rather, we expected that this small slope would produce older soils than other side of hill, with its steep gradient. Club de Campo investigations are continuing.

\section{Boconó series}

Sandy alluvial soil profile, in pasture $2 \mathrm{~km}$ from M.O.P. (Ministerio de Obras Publicas) sta., $100 \mathrm{~m}$ from Boconó (Boconoito)-Puerto Nutrias rd., state of Barinas, Venezuela ( $8^{\circ} 42^{\prime} \mathrm{N}$ Lat, $69^{\circ} 52^{\prime} \mathrm{W}$ Long), W Llanos Altos region. Sediments formed from overflowing of Boconó R., which has since changed course. It was thought that this soil might date previous to those of next 2 series. Coll. 1970 by R. Herrera and J. García and subm. by R. Herrera and M. A. Tamers.

IVIC-706. Boconó, 0 to $0.10 \mathrm{~m} \quad 104.8 \pm 0.8 \%$ modern From A horizon, $2.1 \%$ non-rootlet non-carbonate carbon content. 
IVIC-707. Boconó, 0.10 to $0.25 \mathrm{~m}$

From A horizon, $1.3 \%$ non-rootlet, non-carbonate carbon content.

IVIC-708. Boconó, 0.25 to $0.50 \mathrm{~m}$

$1160 \pm 70$

From $\mathrm{C}$ horizon, $0.14 \%$ non-rootlet, non-carbonate carbon content.

\section{IVIC-709. Boconó, 0.50 to $0.75 \mathrm{~m}$}

From $\mathrm{C}$ horizon, $0.09 \%$ non-rootlet, non-carbonate carbon con.c. General Comment: ages increase and carbon contents decrease regularly with depth. This series was from bank of previous position of Boconó $\mathrm{R}$. Soil is very permeable and recent carbon infiltration into deeper levels should be at maximum here. Nevertheless, deepest sample, IVIC-709, is still quite old.

\section{Fanfurria series}

Sandy loam, alluvial, soil samples from M.O.P. sta. on Boconó (Boconoito)-Puerto Nutrias rd., state of Barinas, Venezuela $\left(8^{\circ} 42^{\prime} \mathrm{N}\right.$ Lat, $69^{\circ} 56^{\prime} \mathrm{W}$ Long). Deposits from overflowing of Boconó R., while in earlier position. Intermediate between Boconó series and Méndez series. Coll. 1970 by R. Herrera and J. García and subm. by R. Herrera and M. A. Tamers.

IVIC-710. Fanfurria, 0 to $0.15 \mathrm{~m} \quad 106.9 \pm 0.8 \%$ modern $1.4 \%$ non-rootlet, non-carbonate carbon content.

IVIC-711. Fanfurria, 0.15 to $0.30 \mathrm{~m} 106.6 \pm 0.8 \%$ modern $0.70 \%$ non-rootlet, non-carbonate carbon content.

\section{IVIC-712. Fanfurria, 0.30 to $0.45 \mathrm{~m}$}

$0.58 \%$ non-rootlet- non-carbonate carbon content.

\section{IVIC-713. Fanfurria, 0.45 to $0.60 \mathrm{~m}$}

$0.52 \%$ non-rootlet, non-carbonate carbon content. in the Boconó series.

\section{Méndez series}

Clayey alluvial soil from M.O.P. sta. on Boconó (Boconoito)-Puerto Nutrias rd., state of Barinas, Venezuela ( $8^{\circ} 41^{\prime} \mathrm{N}$ Lat, $69^{\circ} 56^{\prime} \mathrm{W}$ Long). Deposits in furthest position from bed of previous Boconó R. Downhill from Boconó and Fanfurria series. Coll. 1970 by R. Herrera and J. García and subm. by R. Herrera and M. A. Tamers.

IVIC-714. Méndez, 0 to $0.12 \mathrm{~m}$ $109.8 \pm 0.8 \%$ modern $2.0 \%$ non-rootlet, non-carbonate carbon content. 
IVEA.715. Méndez, 0.12 to $0.25 \mathrm{~m}$

(1.,3\% non-rootlet, non-carbonate carbon content.

1YC.716. Méndez, 0.25 to $0.40 \mathrm{~m}$

0.5. non-rootlet, non-carbonate carbon content.

\section{1. $=717$. Méndez, 0.40 to $0.55 \mathrm{~m}$}

a.s non-rootlet, non-carbonate carbon content.

IVIC 78 . Méndez, 0.55 to $0.70 \mathrm{~m}$

a. "non-rootlet, non-carbonate carbon content.

\section{1 -7 19. Méndez, 0.70 to $0.85 \mathrm{~m}$}

A.D. 1490

$460 \pm 70$

$940 \pm 60$

A.D. 1010

$1690 \pm 60$ A.D. 260

$2540 \pm 80$ 590 B.c.

$$
2530 \pm 80
$$
580 B.c.

(inmal commoni: ages increasing and carbon contents decreasing regulan wh: dopth. At cunivalent levels, dates for these thre serics are

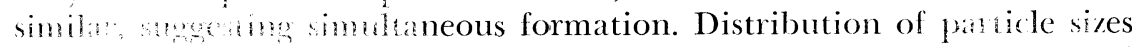
is dro to malle partes, i.c., clay, being transporied more casily and thus haber by the looding of previous Bocono river. Assumption

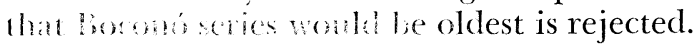

IV. GOLOGIG SAMPLE

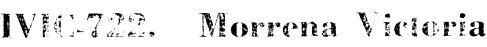 \\ $5179 \pm 80$ \\ \%.2.}

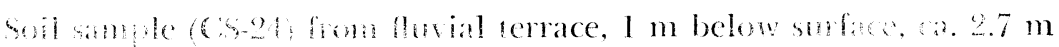

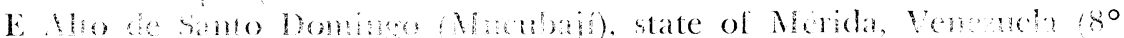

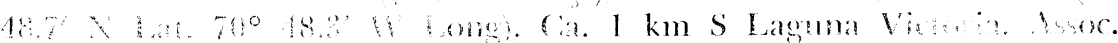

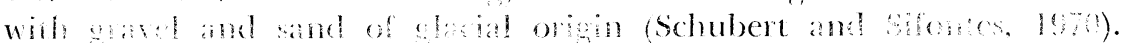

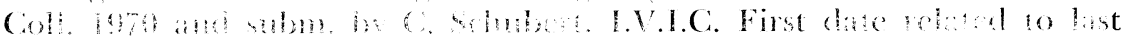

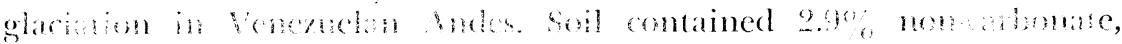

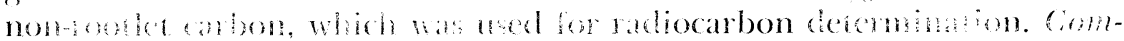

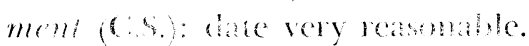

\section{WXIRWIREASTRIAL, SAMPLE}

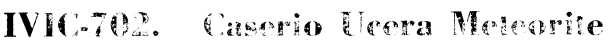

$34.4+2 \cdot 1 / \mathrm{mm} / \mathrm{kg}$

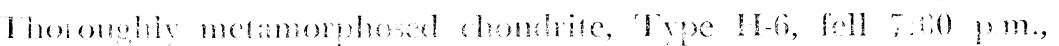

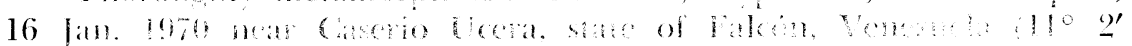

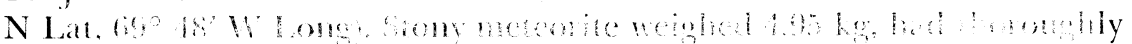

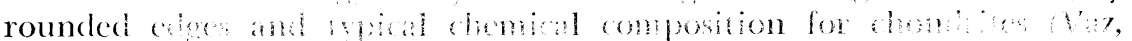
1970). Fall bead by vinge inhahitants, who coll. meteonte hie all warm. Obtamed by I: Var, I.V.M.C., a few days later. Sample for atocarbon analysis was waten from surface and heated at ca. 10000 f for $48 \mathrm{hr}$ in oxygen stream. Polyethylene plastic used as carrier. Comment (M.A.T.): radiocarbon content is ca. $1 / 2$ that of other "fall" stone meteorites we have measured, average value: $85 \mathrm{dpm} / \mathrm{kg}$. It is also low in 
comparison with accelerator measured cross section data for $\mathrm{O}^{16}(\mathrm{p}, 3 \mathrm{p}) \mathrm{C}^{14}$ (Tamers, 1963). There was no indication that Caserio Ucera had recently been transferred from a larger body, which would have meant that it had been irradiated only on one side. Other stone meteorite "Falls" showed average radiocarbon contents of $65 \mathrm{dpm} / \mathrm{kg}$ (Goel and Kohman, 1962) and $48 \mathrm{dpm} / \mathrm{kg}$ (Suess and Wänke, 1962). Caserio Ucera has lowest value so far observed.

\section{REFERENCES}

Benzler, J. H. and Geyh, M. A., 1966, Versuch einer zeitlichen Gliederung von DwogHorizonten mit Hinweisen auf die Problematik der ${ }^{14} \mathrm{C}$-Datierung von Bodenproben: Deutsch geol. Gesell. Zeitschr., v. 118, p. 361-367.

Buckley, J. D. and Willis, E. H., 1969, Isotopes' radiocarbon measurements VII: Radiocarbon, v. 11, p. 53-105.

Cruxent, José M., 1967, El paleo-indio en Taima-taima, estado Falcón, Venezuela: Acta Cient. Venezolana Supp. 3, p. 3-17.

Goel, P. S. and Kohman, T. P., 1962, Cosmogenic carbon-14 in meteorites and terrestrial ages of "finds" and craters: Science, v. 136, p. 875-876.

Scharpenseel, H. W. and Pietig, F., 1969, Altersbestimmung von Böden durch die Radiokohlenstoffdatierungsmethode III. Böden mit $B_{t}$-Horizont und fossile Schwarzerden: Pflanzenernährung Bodenkunde Zeitschr., v. 122, p. 145-152.

Scharpenseel, H. W., Tamers, M. A., and Pietig, F., 1968, Altersbestimmung von Böden durch die Radiokohlenstoffdatierungsmethode. I. Methode und vorhandene ${ }^{14} \mathrm{C}$ Daten: Pflanzenernährung Bodenkunde Zeitschr., v. 119, p. 34-44.

Schubert, Carlos and Sifontes, R. S., 1970, Bocono Fault, Venezuelan Andes: Evidence of Postglacial movement: Science, v. 170, p. 66-69.

Stuiver, Minze, 1969, Yale natural radiocarbon measurements IX: Radiocarbon, v. 11, p. $545-658$.

Suess, H. E. and Wänke, H., 1962, Radiocarbon content and terrestrial age of twelve stony meteorites and one iron meteorite: Geochim. et Cosmochim. Acta, v. 26, $475-480$.

Tamers, M. A., 1963, Détermination des sections éfficaces de quelques réactions nucléaires intervenant dans les effets du rayonnement cosmique: C.E.A. Rap., v. 2298, p. 1-61.

1966, Instituto Venezolano de Investigaciones Científicas natural radiocarbon measurements II: Radiocarbon, v. 8, p. 204-212.

1969a, Instituto Venezolano de Investigaciones Científicas natural radiocarbon measurements IV: Radiocarbon, v. 11, p. 396-422. 1969b, Datage non destructif des os fossiles: Acad. sci. [Paris] Comptes
rendus, v. 268D, p. 489-492.

carbon measurements V: Radiocarbon, v. 12, p. 509-525.

Tamers, M. A. and Scharpenscel, H. W., 1970, Scquential sampling of radiocarbon in ground water, in: Use of isotopes in hydrology, I.A.E.A., Vienna, in press.

Vaz, J. E., 1970, Mineralogia y composicion química del meteorito "Caserio Ucera": Acta Cient. Venezolana, in press.

Wagner, Erika, 1967, The prehistory and ethnohistory of the Carache area in western Venezuela: Yale Univ. pub. in Anthropol., no. 71. 